특집논문-09-14-4-04

$$
\text { 이동형 패럴랙스배리어와 시점 추적을 이용한 3D 디스플레이 시스템 }
$$

\author{
채 호 병a), 유 영 록a), 이 강 성 $)^{a}$, 이 승 현 $)^{\ddagger}$
}

\title{
Autostereoscopic 3D display system with moving parallax barrier and eye-tracking
}

\author{
Ho-Byung Chae ${ }^{\text {a) }}$, Young-Roc Ryu ${ }^{\text {a)}}$, Gang-Sung Lee ${ }^{\text {a)}}$, and Seung-Hyun Lee ${ }^{\text {a) }}$
}

요 약

본 논문에서는 시점의 움직임에 대해 최적의 자연스러운 스테레오 영상을 관찰자에게 제공할 수 있는 시점추적시스템을 제안하였 다. 관찰자의 위치를 추적하기 위한 시점추적시스템은 관찰자와 배경의 상대적인 거리를 측정하여 배경으로부터 관찰자를 분리할 수 있다. 시점추적을 위한 키 신호를 얻는 방법으로 TOF(Time-Of-Flight) 이론으로 만들어진 깊이 카메라(depth camera)를 사용하였다. 또한 관찰자의 위치가 제한되는 고정형 패럴랙스배리어의 단점을 보완하는 방법으로 이동형 패럴랙스배리어를 제안하였다.

\begin{abstract}
We present a novel head tracking system for stereoscopic displays that ensures the viewer has a high degree of movement. The tracker is capable of segmenting the viewer from background objects using their relative distance. A depth camera using TOF(Time-Of-Flight) is used to generate a key signal for eye tracking application. A method of the moving parallax barrier is also introduced to supplement a disadvantage of the fixed parallax barrier that provides observation at the specific locations.
\end{abstract}

Keywords : parallax barrier, autostereoscopic display, eye-tracking system, time-of -flight, depth camera

\section{I. 서 론}

입체 영상을 보기 위해 특별한 안경을 쓴다는 것은 귀챃 은 일이다. 특수한 안경을 사용하지 않는 입체 디스플레이 를 만드는 것은 입체에 관한 연구를 하는 사람들의 꿈이었 으며, 일반적으로 좌우 시차 영상을 분리하여 두 눈으로 볼

a) 광운대학교대학원 정보디스플레이학과

Dept. of Information Display, Graduate School of Kwangwoon University

\# 교신저자 : 이승현 (shlee@kw.ac.kr)

※ 이 논문은 지식경제부 및 정보통신연구진흥원의 IT산업원천기술개발사업 의 일환으로 수행하였음. [2009-F-208-01, 대화형 디지털 홀로그램 통합서

비스 시스템의 구현을 위한 신호처리 요소 기술 및 $\mathrm{SoC}$ 개발]

- 접수일(2009년3월14일),수정일(2009년7월23일),게재확정일(2009년7월23일)
수 있도록 패럴랙스배리어나 렌티큘러 스크린 등의 광학 판을 디스플레이 화면의 앞, 또는 뒤에 설치하는 방식을 사 용한다 ${ }^{[1-3]}$. 이들 방식은 일반적으로 유효 시야가 상당히 좁 고, 한 사람 밖에 이용하지 못했지만 최근 여러 명의 관찰자 도 함께 시청할 수 있는 다시점 입체 디스플레이가 발표되 는 등 차세대 디스플레이로써 주목을 받고 있다 ${ }^{[4]}$.

패럴랙스배리어의 경우는 $2 \mathrm{D} / 3 \mathrm{D}$ 겸용으로 사용할 수 있 는 장점으로 개인이 주로 사용하는 핸드폰, 노트북등과 같 은 소형 디스플레이에 그 응용이 활발히 진행되고 있다 ${ }^{[5][6]}$. 그러나 위치 고정적이란 고질적인 단점을 가지고 있어 사 용자들이 $3 \mathrm{D}$ 영상을 관찰하기 위해서는 시점을 좌우영상 
에 맞추어야 하는 단점을 가지고 있다. 즉, 사용자가 수평으 로 움직일 경우 좌우영상이 역전되는 현상이 발생하게 되 어 시점의 증가나 시점추적과 같은 해결책이 요구된다 ${ }^{[7][8]}$. 일반적인 패럴랙스배리어 방식을 적용한 3D 디스플레이 시스템의 원리는 관찰자의 좌안에는 좌영상이, 우안에는 우영상이 보여 지게 되어 입체를 느낄 수 있게 되는데, 관찰 자가 좌. 우로 이동하면 좌안에 우영상이, 우안에 좌영상이 보이게 되며 이러한 경우 입체감을 느낄 수 없고 어지럼증 을 유발 시키는 단점이 있다. 이러한 문제점을 해결하기 위 하여 고안된 방안이 시점 추적형 알고리즘을 적용한 패럴 랙스배리어 디스플레이 시스템이다. 시점을 추적하여 디스 플레이 하는 방식으로는 관찰자의 움직임에 따른 $\mathrm{x}-\mathrm{y}-\mathrm{z}$ 좌 표를 추출해서 디스플레이 장치에 표시되는 좌영상과 우영 상을 각 위치에 맞도록 서로 교차 시키는 방법이 있고, 관찰 자의 시점을 추적하여 관찰자의 위치에 맞게 패럴랙스배리 어를 스위칭 하는 방법이 있다.

본 논문에서는 이 문제점에 대한 보완책으로 시점추적시 스템에서 활용할 수 있는 이동형 패럴랙스배리어 패널을 이용한 시점추적시스템을 제안하였다. 이동형 패럴랙스배 리어는 4개의 서브 배리어로 구성하였고, 서브 배리어와의 연결을 위하여 640 라인 FPC(Flexible Printed Circuit)로 구 성된 새로운 교차커넥터를 설계하였다. 관찰자의 위치를 추적하기 위한 시점추적시스템의 영상획득은 TOF 이론에 근거한 깊이 카메라를 사용하였다 ${ }^{[9]}$. 카메라를 통해 추출된 좌표 값은 시리얼 통신을 통해 모니터의 전면부에 장착된 이동형 패럴랙스배리어를 시점에 맞게 전기적으로 구동 제 어하게 된다. 컴퓨터 시뮬레이션을 통해 일반적인 시스템 과의 성능을 비교하였다.

\section{II. 이동형 패럴랙스배리어}

패럴랙스배리어 방식은 일정한 위치에서만 관찰 된다는 단점을 가지고 있는데, 본 논문에서는 이러한 단점을 보완 할 수 있는 이동형 패럴랙스배리어 방식을 제안하였다. 일 반적인 패럴랙스배리어는 배리어와 개구부의 일정한 간격 을 가지고 있는 구조이며 배리어 사이에 있는 개구부로 영 상이 투과되어 사용자가 입체를 볼 수 있게 해준다. 이러한
방법을 이용하여 디스플레이 장치를 구성하게 되면 정확한 위치에서만 영상의 시청이 가능해진다. 즉, 사용자가 수평 으로 움직일 경우 좌우영상이 역전되는 현상이 발생하게 되며, 이를 해결하기위한 방법으로 시점추적을 이용하는 시스템이 소개되고 있다마.

패럴랙스배리어를 사용하는 시점추적시스템의 경우, 카 메라의 시점 추적 결과에 따라 좌우 눈의 위치가 바뀌게 되면 소프트웨어적으로 좌우 영상을 절환 하여 주게 되는 데, 최적 시점이 아니어도 좌우 눈의 위치가 경계를 넘지 않는 다면 그대로 영상을 유지하게 된다. 즉, 수평으로 어느 범위 내에서는 좌우 영상이 바뀌지 않았어도 $3 \mathrm{D}$ 영상을 관 찰할 수 있으며, 이에 따라 최적 시점이 제한되는 단점을 지니게 된다. 이를 해결하는 방법으로 이동형 패럴랙스배 리어를 구성할 수 있다. 이동형 패럴랙스배리어를 이용한 시점추적시스템에서는 미세한 시점의 이동에 따라 배리어 가 이동하여 줌으로써 항상 최적의 좌우 시점을 유지할 수 있게 된다. 즉, 최적의 $3 \mathrm{D}$ 관찰 시점이 많아짐에 따라 항상 자연스러운 $3 \mathrm{D}$ 영상을 시청할 수 있다.

본 논문에서는 이동형 패럴랙스배리어를 사용함으로써 제한된 최적 시점 수에 대한 문제를 해결할 수 있었고, 미 세한 시점의 움직임에 대해 최적의 $3 \mathrm{D}$ 시청 시점을 제공 하여 자연스러운 스테레오 영상을 관찰자에게 제공할 수 가 있었다.

그림 1 은 일반적인 패럴랙스배리어의 구조이며, 그림 2 는 본 논문에서 구성한 이동형 패럴랙스배리어 패널을 보 여준다. 그림 2에서는 배리어와 슬릿을 각각 4 개의 작은 라 인으로 구성하였고, 사용자의 이동에 따라 배리어를 이동 하게 되면 어느 위치에서든 최적의 $3 \mathrm{D}$ 영상을 시청 할 수 있게 된다.

일반적으로 사용되는 한 개의 배리어를 몇 개의 서브 배 리어로 분리 할 것인가에 대해서는 실험을 통해 확인하였 다. 배리어 간의 간격이 너무 좁을 경우에는 공정상의 문제 뿐만 아니라 $\mathrm{TN}$ 패널로 제작을 할 경우 두 라인 간에 합선 현상이 발생하게 되어 이동형 패럴랙스배리어가 정상적으 로 작동 되지 않는다. 본 실험에서는 각 라인 사이의 간격이 $3 \mathrm{D}$ 디스플레이에 미치는 영향을 알아보기 위하여 우선 필 름으로 제작 하여 테스트 하였다. 각각의 서브 라인 사이 
간격을 $5 \mu \mathrm{m}, 10 \mu \mathrm{m}, 15 \mu \mathrm{m}, 20 \mu \mathrm{m}$ 단위로 설계하여 $3 \mathrm{D}$ 디스플 레이를 테스트 하였다. 실험 결과 각 서브 라인의 간격을 $10 \mu \mathrm{m}$ 이상으로 제작을 하였을 경우 라인 사이로 빛이 통과 하여 올바른 패럴랙스배리어의 기능을 수행 하지 못했다. $5 \mu \mathrm{m}$ 이하가 제일 효과가 좋았지만 현재 $\mathrm{TN}$ 패널의 제조 공 정에서 제작 가능한 최소 간격이 $8 \mu \mathrm{m}$ 라는 점을 고려하여 서 브 배리어 사이의 간격을 $8 \mu \mathrm{m}$ 로 하였다.

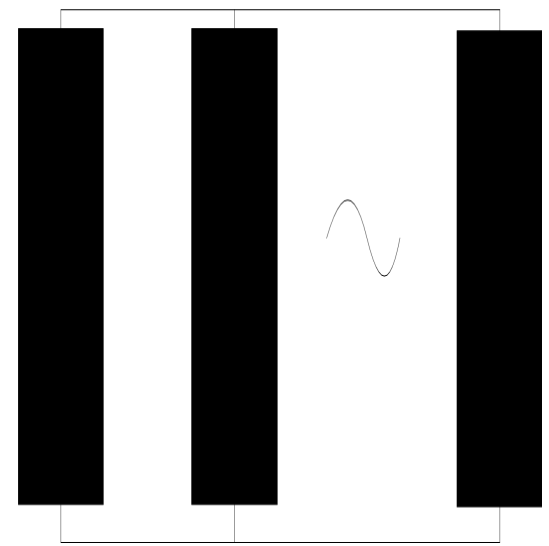

그림 1. 일반적인 패럴랙스배리어

Fig. 1. Conventional parallax barrier

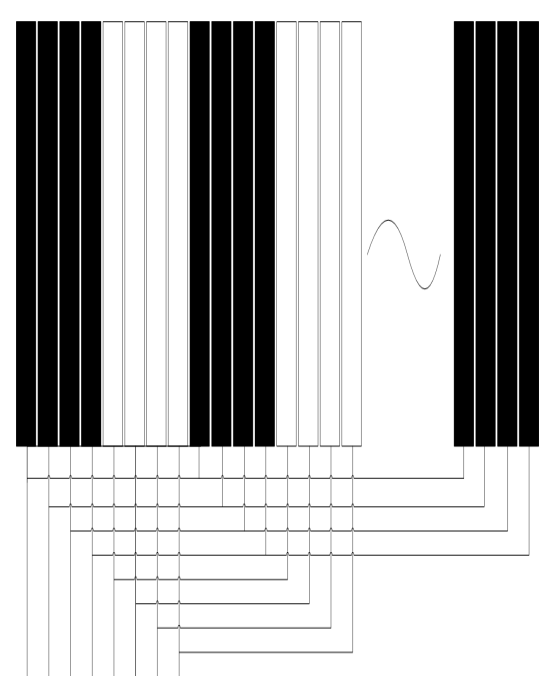

그림 2. 이동형 패럴랙스배리어

Fig. 2. Moving parallax barrier

그림 3 에서와 같이 각 서브 라인 사이의 간격을 $8 \mu \mathrm{m}$ 로
제작하여 패널의 수명에 영향을 미치지 않을 정도의 전압 을 걸어주면, 서브 라인 사이의 슬릿으로 빛이 새지 않을 정도로 라인 사이의 번짐 현상이 발생하며 각 라인간의 합 선 현상은 발생하지 않는다. 이와 같이 설계된 이동형 패럴 랙스배리어의 전기적 접속은 8 개를 1 조로 하여 구성되며, 배리어 1번, 9번, 17 번...이 전기적으로 서로 연결된다. 같은 방식으로 2 번 배리어는 10 번, 18 번...째 배리어와 전기적으 로 연결되어 동작하게 된다.

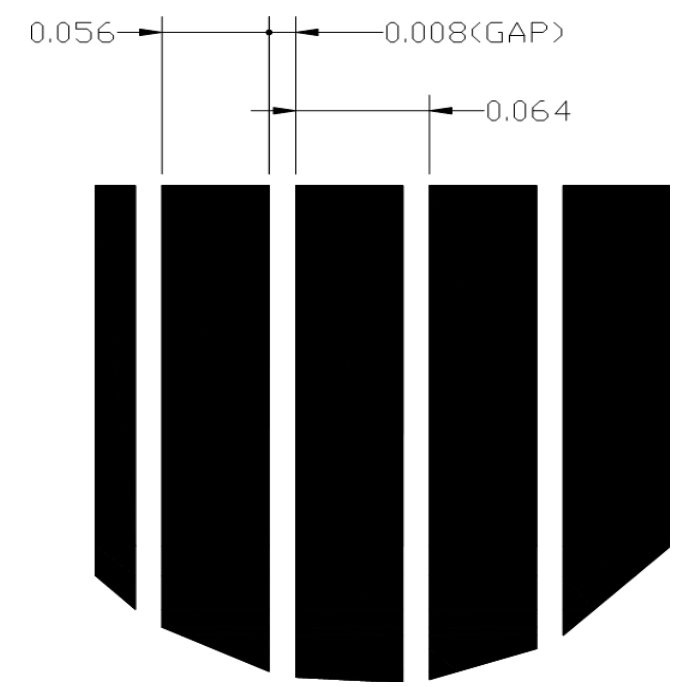

그림 3. 이동형 패럴랙스 베리어 패널의 설계

Fig. 3. Design of moving parallax barrier panel

그림 4는 이동형 패럴랙스배리어의 원리를 보여준다. 그 림 4 의 왼쪽 그림에서와 같이 처음에 $1,2,3,4$ 번 라인이 구동되어 배리어가 형성 되었는데, 관찰자가 오른쪽 그림 에서와 같이 우측으로 이동하게 되면 $3,4,5,6$ 번 라인이 구동이 되어 마치 패럴랙스배리어가 이동을 하는 것과 같 은 효과를 주게 된다. 마찬가지로 관찰자가 좌측으로 이동 하게 되면 상기의 경우와 반대로 작동을 하게 된다. 이러한 방법을 이용하여 관찰자의 위치를 추적하여 각각의 위치에 맞게 패럴랙스배리어가 이동되도록 한다. 그림 4 와 같은 이 동형 패럴랙스배리어를 구동하기 위한 구동 ITO 라인은 그 림 5 와 같이 구성 되어야 한다.

패널 설계에 있어서 패럴랙스배리어의 각 서브 라인은 가격이 저렴한 TN-LCD기술을 이용하여 구성 한다. 그림 

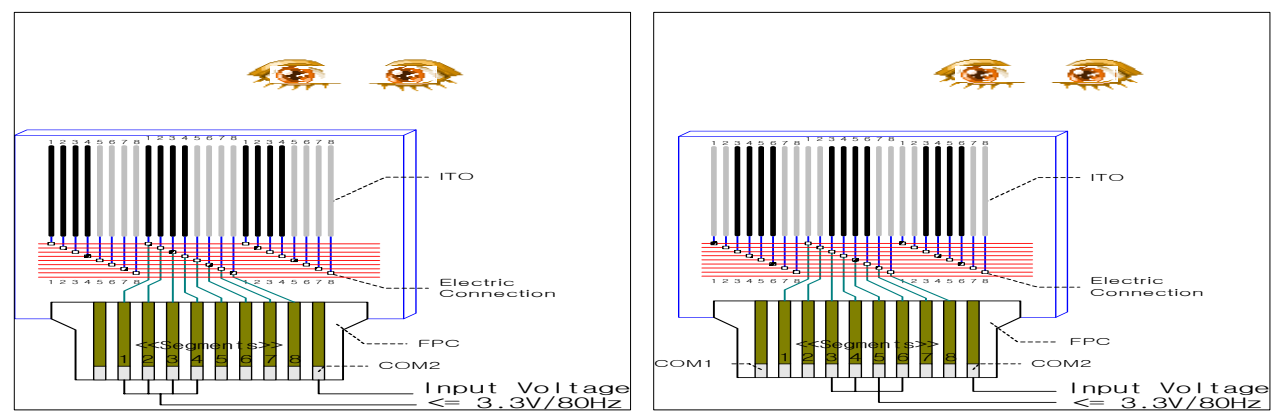

그림 4. 이동형 패럴랙스배리어 패널의 구동원리

Fig. 4. Operating principle of moving parallax barrier panel

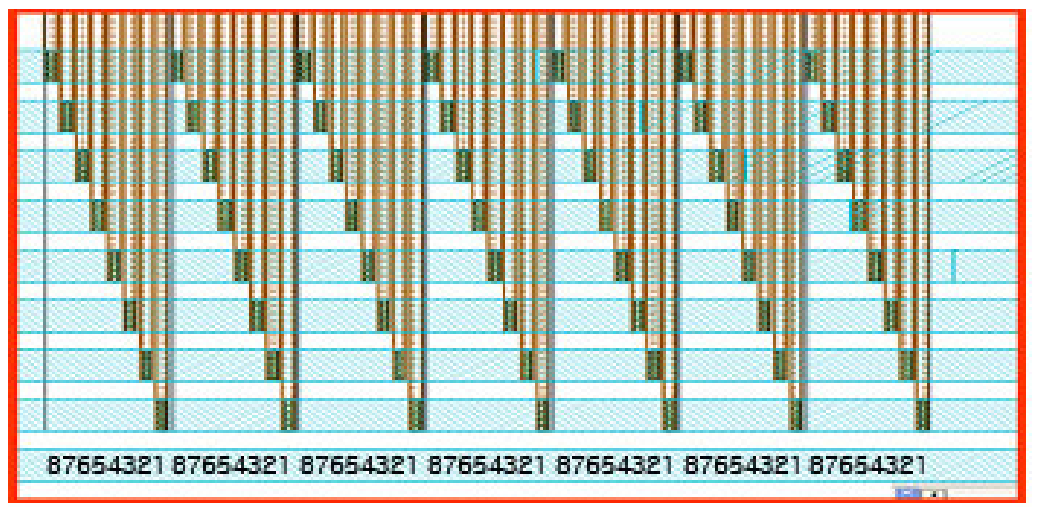

그림 5. 이동형 패럴랙스배리어 패널의 도선 연결

Fig. 5. Line connection of moving parallax barrier panel

5 와 같은 구동 라인을 $\mathrm{TN}$ 패널에 적용하여 구성 할 경우에 는 고가의 TFT의 정밀한 기술력이 사용되어야 한다. 또한, 패널을 만들 때 마다 그 패널에 맞는 새로운 구동라인을 구성해야 하기 때문에 단가 상승의 요인이 되고 이러한 구 성은 매우 비효율적인 생산 구조를 갖게 된다. 이와 같은 문제를 해결하기 위하여 본 논문에서는 640 라인을 1 개의 묶음으로 하는 정밀도가 높은 일반 $\mathrm{TN}$ 패널을 이용한 교차 커넥터(crossing connector)를 제작하였다. 이 교차커넥터 는 TFT 라인을 사용하지 않고, 모든 패널에 적용할 수 있는 장점을 제공한다.

\section{III. 깊이 카메라를 이용한 시점추적 알고리듬}

본 논문에서는 시점 추적을 위해 일반 카메라가 아닌 깊 이 카메라를 사용하였다. 일반 카메라나 웹 카메라는 단순
히 패턴 인식만을 사용하기 때문에 처리 시간이 길어지거 나 다수의 관찰자가 있을 경우 원하는 목표를 찾지 못하는 단점이 있다. 반면 깊이 카메라는 특정 거리에 있는 관찰자 만 골라낼 수 있기 때문에 오류 인식의 가능성을 최대한 제외시킬 수 있다.

깊이 카메라에서 거리 측정은 $\mathrm{TOF}$ 원리로 만들어지며, 이 깊이 카메라는 그레이 레벨 이미지와 동시에 3 차원 정보 를 영상에서 구해낸다 ${ }^{[9]}$. 기본적인 개념은 적외선 $\mathrm{LED}$ 를 이용하여 매우 짧은 펄스 $(20 \mathrm{MHz})$ 로 발광 시키고 물체에 서 반사되어 돌아오는 빛의 위상 시간차를 계산해서 깊이 값을 찾아내는 방식으로 마치 레이더와 같은 개념이 적용 된 카메라이다. 측정된 거리는 카메라에서 물체까지 진행 한 빛의 시간에 비례한다.

깊이 카메라는 $870 \mathrm{~nm}$ 의 파장을 발생시키는 55 개의 적외 선 $\mathrm{LED}$ 로 사인파를 $800 \mathrm{~mW}$ 의 전력으로 발광시킨다. 적외선 
빛의 주파수가 $20 \mathrm{MHz}$ 일 경우 측정거리는 $7.5 \mathrm{~m}$ 의 범위 를 가지며 주파수를 낮추면 해상도는 떨어지지만 더 먼 거 리 까지 측정이 가능하다. 이미지 센서인 $\mathrm{CMOS} / \mathrm{CCD}$ 는 $0.8 \mu \mathrm{m}$ 의 기술로 $\mathrm{ZMD}$ 사에서 제작 되었다. $\mathrm{CMOS}$ 의 각 픽 셀은 "two-tap" 구조를 기초로 하고 있다. 이것은 각 픽셀 이 두 개의 용량과 두 개의 아날로그 출력으로 구성되었 다는 의미이며, 센서 값은 $10 \mathrm{Mega}$ Samples/sec 주기로 읽어 낸다.

센서의 2 개의 아날로그 출력들은 12 비트의 $\mathrm{A} / \mathrm{D}$ 컨버터 에 의해 디지털 값으로 바꾼다. 이 데이터는 고속 데이터 처리 소자인 FPGA에서 처리하고 RAM에서 버퍼링 하게 된다. FPGA(Field Programmable Gate Array) 컨트롤은 카 메라의 신호 처리와 8-bit D/A 컨버터에 의해 여러 제어 신호를 만들어낸다. FPGA는 물체에서 반시되어 들어온 광파를 거리 요소인 위상지연과 밝기 성분인 오프셋 그리 고 진폭의 연산의 역할을 한다. 또한 카메라를 제어하는 다양한 파라미터의 데이터 처리는 USB 포트를 통해 직접
처리한다.

본 논문에서는 깊이 카메라를 사용한 시점 추적형 알고 리즘을 이동형 패럴랙스배리어에 적용하였다. 깊이 카메라 를 이용하여 배경과 관찰자의 얼굴윤곽을 실시간으로 추출 하고 정확한 눈의 위치를 컴퓨터로 알려줌으로써, 눈의 위 치에 맞는 패럴랙스배리어를 형성시켜 자연스러운 입체 영 상을 관찰할 수 있도록 하였다. 실험에 사용된 깊이 카메라 는 스위스 CSEM사 에서 개발된 SR-3000모델이며, 입력 영상은 $176^{*} 144$ 픽셀, $16 \mathrm{bit}$ 해상도이다.

그림 6은 3단계의 인식 시스템 흐름도를 나타낸다. 첫 번 째는 깊이 값 분리부 이며 여기서는 깊이 카메라의 기능 중에 영상과 거리감 데이터를 USB 포트를 통해 받고 특정 거리 이외의 정보는 제거한다. 표시에서 전처리 부분이 이 에 해당한다. 두 번째는 주 처리부는 분리된 얼굴 영역에서 눈의 모양을 템플릿 매칭 방식으로 필터링 한 후 좌. 우 두 개의 눈임이 확인될 때 두 눈의 좌표를 평균치 연산한다. 세 번째는 두 번째 부에서 연산한 X-좌표의 값을 입체영상
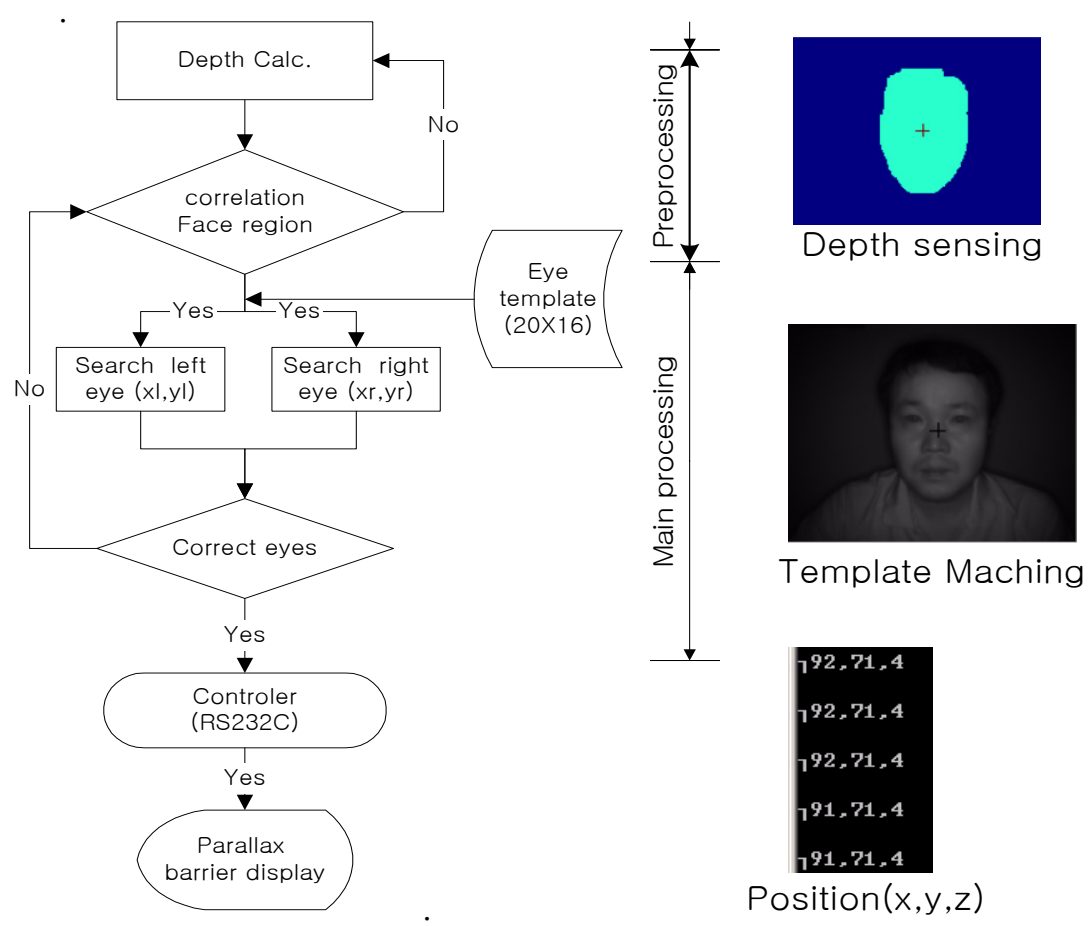

그림 6. 인식 시스템 흐름도

Fig. 6. Flowchart for a position recognition 
이 잘 보이는 실제 $\mathrm{X}$-좌표로 변환한 후 시리얼 $(\mathrm{RS} 232 \mathrm{C})$ 통신으로 패럴랙스배리어가 장착된 모니터로 전송함으로 써 입체 영상을 자연스럽게 시청이 가능하게 하는 시스템 이다. 세부적으로 주 처리부는 전처리에서 찾은 얼굴 영역 으로 부터 좌우 두 눈의 좌표를 템플릿 매칭 방법을 이용하 여 산출해 내어 나란히 있는 두 눈의 후보영역 내에 관찰자 의 두 눈이 위치해 있으면 관찰자와 모니터와의 위치 좌표 에 의해 형성될 이동형 패럴랙스배리어의 배열을 결정 하 게 된다.

\section{IV. 실험 및 결과 고찰}

\section{1. 교차커넥터를 사용한 이동형 패럴랙스배리어 제작}

현재 상용화 되고 있는 노트북에 이동형 패럴랙스배리어 를 설계 및 제작하여 적용하였다. 사용된 노트북은 Asus사 제품으로 15.4 "의 TFT-LCD의 해상도는 1280 x 800이다. 그림 7에서와 같이 640 라인을 1 개의 묶음으로 하여 상하 4 개씩의 입력 단자를 배치한 형태로 $\mathrm{TN}$ 패널을 제작하였다. 그림 8 은 640 라인을 8 의 배수배로 같은 동작이 되는 교

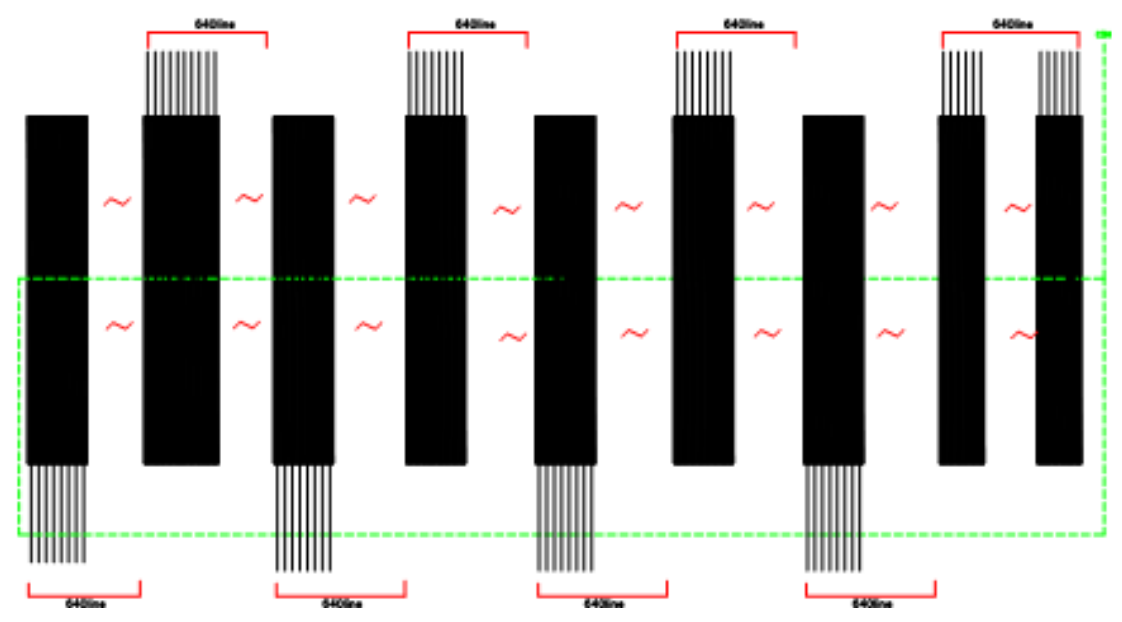

그림 7. 15.4" 이동형 패럴랙스배리어 TN 패널

Fig. 7. 15.4" moving parallax TN panel

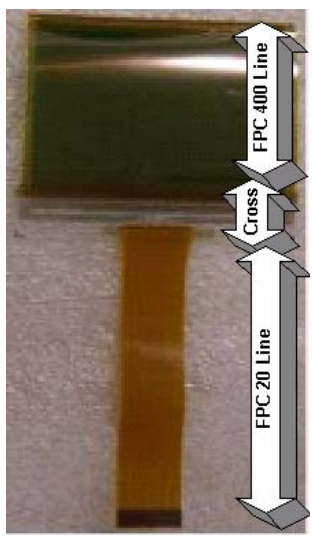

(a)

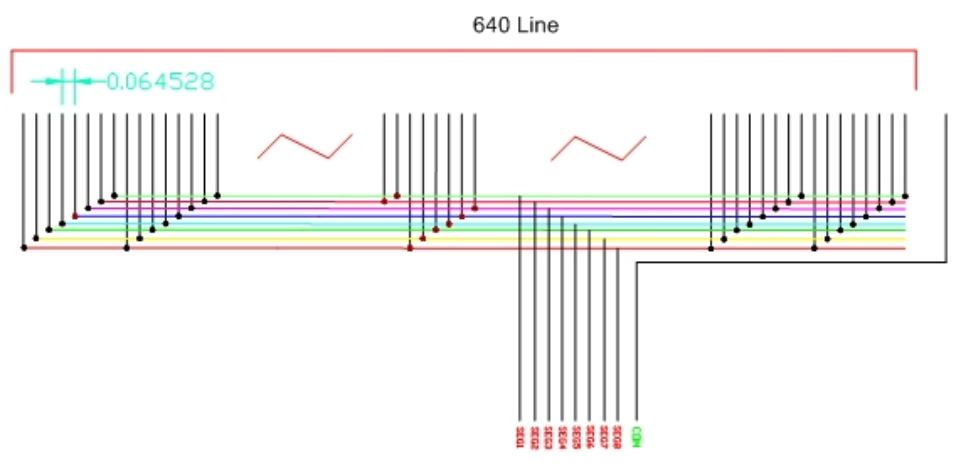

(b)

그림 8. (a) 제작된 교차커넥터 (b) 교차커넥터 개념도

Fig. 8. (a) Manufactured cross connector (b) Cross connector block diagram 
차커넥터 이다. 그림 $8(\mathrm{a})$ 는 교차커넥터의 제작된 사진이며, 그림8(b)는 개념도이다. 이동형 패럴랙스배리어의 $\mathrm{TN}$ 패널 은 각 라인의 구동을 위해 그림 9 와 같이 8 개의 교차커넥터 를 위 아래로 부착하였다. 그림 8에서 640라인의 $\mathrm{FPC}$ 로 제 작된 교차커넥터 위쪽의 넓은 부분은 그림 9 와 같이 패널에 연결 하도록 하였다. 아래 좁은 부분은 $1 \sim 8$ 번의 구동을 위 한 8 개의 라인과 $\mathrm{COM}$ 신호가 전달되는 1 개의 라인으로 구성 되어 총 9 라인으로 제작되었으며, 컨트롤 신호를 전달 할 수 있도록 제어보드와 연결된다. 본 실험에서는 신호의 정확한 전달과 라인 사이에서 발생할 수 있는 간섭 현상 등을 고려하여 16 개의 구동 신호를 전달하는 라인과, 2 개의

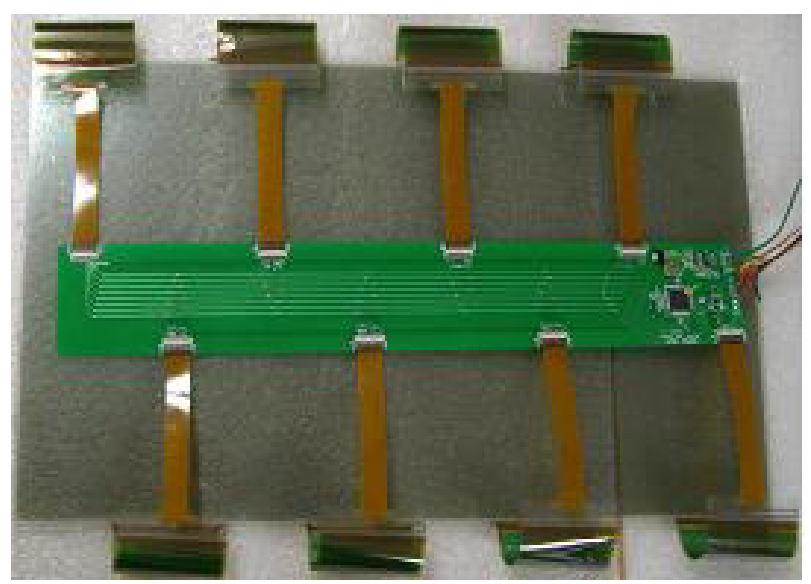

그림 9. 교차커넥터와 $\mathrm{TN}$ 의 결합

Fig. 9. Connection between the panel and control board
$\mathrm{COM}$ 라인, 2 개의 더미 라인으로 총 20 라인의 $\mathrm{FPC}$ 를 이용 하여 제작 하였다.

\section{2. 시리얼 통신을 이용한 시점 추적}

실험에서 사용된 컴퓨터는 $3 \mathrm{D}$ 영상을 출력하는 동시에 이동형 패럴랙스배리어의 재배열 정보는 시리얼통신을 이 용하여 변환하고 이렇게 변환된 신호를 이용하여 이동형 패럴랙스배리어가 포함된 3D 디스플레이를 제어한다. 따 라서 일반 패럴랙스배리어 방식에서 문제가 되었던 관찰자 의 좌우 이동에 따른 영상이 반전되는 현상을 시점 추적알 고리즘과 이동형 패럴랙스배리어를 이용하여 문제점을 해 결함으로써 관찰자가 편안하게 입체 영상을 관찰할 수 있 도록 하였다.

사용된 알고리즘은 거리 $2 \mathrm{~m}$ 이내의 정보만 취득하게 설 정하고 영상의 값은 8 비트 분해능 중에 제한 값으로 100 을 설정하였다. 특정 거리로 제한된 영상은 정상적인 사람의 특성상 위 부분은 머리에 해당되고 아래 부분은 몸에 해당 된 것으로 가정하고 각 단계의 알고리즘을 처리한다. 첫 번 째 영상의 잡음을 제거하기 위해 마스크의 크기를 $3 \times 3$ 으로 하고 2 회의 침식과 5 회의 팽창 알고리즘을 수행하였다. 결 과는 그림 10에서 "depth sensing"의 사진에 해당된다.

얼굴 후보 영역이 추출된 후 실제 얼굴인지를 확인하는 방법으로 템플릿 매칭을 사용하였고 마스크의 크기는 20x16으로 만들었다. 한 쪽 눈을 찾은 후 좌측 또는 우측에

TN_MASK5[9] $=\{$ Ob11111000, 0b01111100, 0b00111110, 0b00011111, 0b10001111, 0b11000111, 0b11100011, 0b11110001,0\};

$\operatorname{MASK}(0)$

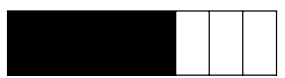

$\operatorname{MASK}(4)$

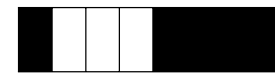

그림 10.8가지 TN 구동 형태

Fig. 10. Pattern for 8 kinds of TN control
MASK(2) MASK(3)

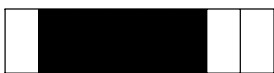

$\operatorname{MASK}(5)$

$\operatorname{MASK}(6)$

$\operatorname{MASK}(7)$
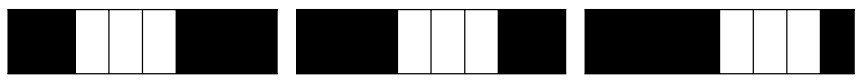
서 나머지 눈을 찾는다. 두 개의 눈이 맞는 다고 판단되면 두 눈의 평균값 좌표 중에 $\mathrm{x}$ 좌표만을 시리얼 통신을 통해 이동형 패럴랙스배리어가 부착된 스테레오 모니터로 전송 하여 이동형 패럴랙스배리어가 눈의 위치에 맞게 전자적인 이동을 하게 한다. 그림 10 은 이동형 패럴랙스배리어의 전 자적 이동의 8 가지 형태를 보여주고 있다.

본 논문에서 제안한 이동형 패럴랙스배리어 방법의 구현 을 위해 ASUS F3J 시리즈 노트북 컴퓨터에 이동형 패럴랙 스배리어 패널을 제작하여 부착 하였다. 실험에 사용된 노 트북의 CPU는 Intel 계열의 Core 2 Duo Processor T7200 Mobile 프로세서이다. 프로그램은 Visual $\mathrm{C}+6.0$ 을 이용하 였으며 사용된 깊이 카메라는 스위스 CSEM 에서 개발된 SR-3000모델이다. 입력 영상의 해상도는 $176 * 144$ 픽셀, 16 비트를 사용하였다.

\section{VI. 결 론}

패럴랙스배리어는 $2 \mathrm{D} / 3 \mathrm{D}$ 겸용으로 사용할 수 있는 장점 으로 개인형 또는 휴대형 $3 \mathrm{D}$ 디스플레이에 많이 응용되고 있다. 그러나 위치 고정적이란 근본적인 문제를 지니고 있 어 사용자들이 $3 \mathrm{D}$ 영상을 관찰하기 위해서는 시점을 좌우 영상에 맞추어야 하는 단점이 있다. 본 논문에서는 이 문제 점에 대한 보완책으로 시점추적시스템에서 활용할 수 있는 이동형 패럴랙스배리어 패널을 제안하였다. 이동형 패럴랙 스배리어의 제작을 위해서는 $\mathrm{TFT}$ 의 정밀한 기술력이 필요 하고 제작비도 높다. 결국, 패널을 만들 때 마다 그 패널에 맞는 새로운 이동형 구동라인을 구성해야 하기 때문에 단 가 상승의 요인이 된다. 본 논문에서는 640 라인을 1 개의 묶음으로 하는 일반 TN 패널을 이용한 교차커넥터를 제안 하였다. 이 교차커넥터는 단순히 이방성 전도 필름(aniso- tropic conductive film, ACF)을 이용하여 모든 패널에 적용 할 수 있는 경제적이고 호환성이 높은 장점을 제공한다.

본 논문에서 구현한 이동형 패럴랙스배리어는 일반적인 패럴랙스배리어를 4 등분하여 사용하게 되므로, 눈의 움직 임에 따라 보다 빠르고 자연스러운 입체 영상을 획득할 수 있는 가능성을 제시해 주었다. 입체 영상의 관찰은 다분히 주관적인 측면이 무시될 수 없으므로 일반적인 시스템과의 성능 비교를 위해 보다 명확한 수치적인 혹은 객관적인 평 가 방법의 연구가 진행되어야 할 과제이다.

\section{참 고 문 헌}

[1] S. H. Kaplan, "Theory of Parallax Barriers," J. SMPTE vol.59, pp.11-21, 1952.

[2] D.J.Sandin, E.Sandor, W.Cunnally, M.Resch, T.DeFanti, M.Brown, "Computer- generated barrier-stripe autostereography", Proc. SPIE, vol.1083, pp.65-75, 1989.

[3] H. Isono, M. Yasuda and H. Sasazawa, "Autostereoscopic 3D LCD Display using LCD-generated Parallax Barrier", 12th Int. Display Research Conf., Japan, Display'92, pp. 303-306, 1992.

[4] 김은수, 이승현 "3차원 영상의 기초" 기다리\&오옴사, pp.129-173, 1998.

[5] A. Jacobs, J. Mather, R. Winlow, D. Montgomery, G. Jones, M. Willis, M. Tillin, L. Hill, M. Khazova, H. Stevenson and G. Bourhill, "2D/3D switchable display," Sharp, Technical Journal no.4, Apr. 2003.

[6] D.S.Kim, S.D.Se, K.H.Cha, and J.P.Ku, " 2D/3D Compatible display by autostereoscopy," Proc. K-IDS Three-Dimensional Display Workshop, pp.17-22, 2006.

[7] Markus Andiel, Siegbert Hentschke, Thorster Elle, and Eduard Fuchs," Eye-tracking for autostereoscopic displays using web cams", Proc. SPIE, vol.4660, pp.200-206, 2002.

[8] O.H.Willemsen, S.T. de Zwart, M.G.H.Hiddink, D.K.G. de Boer, M.P.C.M.Krijin, "Multi-view 3D Display," Society for Information Display 2007 International Symposium Digest of Technical Paper, pp.1154-1157, 2007.

[9] G.J.Iddan, G. Yahav, “ 3D imaging in the studio" Proc. of SPIE 4298, pp.48-55, 2001. 
저 자 소 개

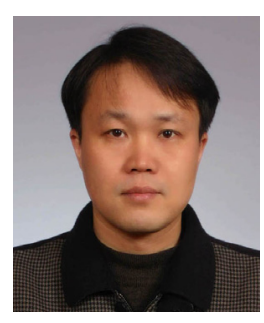

\section{채 호 병}

- 1993년 : 서울산업대학교 전자공학과 공학사

- 1995년 : 광운대학교 전자공학과 공학석사

- 2009년 : 광운대학교대학원 정보디스플레이학과 박사수료

- 주관심분야 : 영상처리, 자동제어, $3 \mathrm{D}$ display

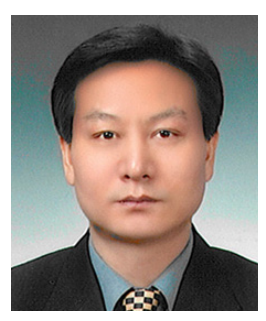

\section{유 영 록}

- 1982년 : 광운대학교 전자공학과 공학사

- 1988년 : 광운대학교대학원 전자공학과 공학석사

- 2009년 : 광운대학교대학원 정보디스플레이학과 박사수료

- 2003년 현재 : 엘림광통신(주) 대표이사

- 주관심분야 : 광통신시스템, 광정보처리, 디지털 홀로그래피

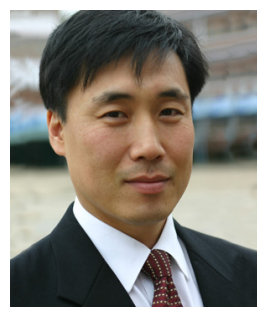

\section{이 강 성}

- 1986년 : 광운대학교 컴퓨터공학과 공학사

- 1988년 : 광운대학교대학원 컴퓨터공학과 공학석사

- 1993년 : 광운대학교대학원 컴퓨터공학과 공학박사

- 2009년 : 서울대학교 음악대학원 작곡과 석사

- 1991년 현재 : 광운대학교대학원 정보디스플레이학과 교수

- 주관심분야 : 신호처리, 음성인식, 컴퓨터음악, 미디어 아트, 예술 공학

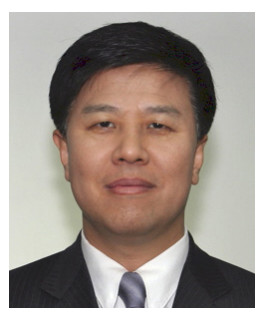

\section{이 승 현}

- 1984년 : 광운대학교 전자공학과 공학사

- 1986년 : 광운대학교대학원 전자공학과 공학석사

- 1993년 : 광운대학교대학원 전자공학과 공학박사

- 1992년 현재 : 광운대학교대학원 정보디스플레이학과 교수

- 주관심분야 : $3 \mathrm{D}$ 디스플레이, 디지털 홀로그래피 